\title{
A NEW APPROACH AND ANALYSIS TO THE ISSUE OF GREAT GAME IN MODERN WESTERN HISTORIOGRAPHY
}

\author{
Radjabov Ozodbek Aminboyevich \\ $\mathrm{PhD}$ researcher of department \\ World History of National University of Uzbekistan
}

Article DOI: https://doi.org/10.36713/epra4217

\begin{abstract}
There are some such problems in world history that do not lose its relevance and significance over the years. As one of such problems, we should mention the English-Russian competition, which began in Asia in the middle of the XIX century, that is, the policy of the "Great game". This issue is reflected in the Monographs of major historians, politicians and experts of the world, in the articles of many textbooks, magazines and newspapers devoted to international relations and diplomacy. Initially, the process of the struggle between the two imperialist countries England and Russia, which began, over the years, has accumulated a huge number of countries around itself. This area of struggle covered very large areas of the Eurasian region and brought out political, economic, social problems, which were extremely complex. In the following article, the conflict of interests of the imperialist powers in Central Asia, the emergence of a sharp geopolitical situation are analyzed from the point of view of historiography.
\end{abstract}

\section{DISCUSSION}

The concept of "Great game" was first used in 1840 by Captain Arthur Connolly of the Ost-India company (1807-1842) [1:181]. Later, this term entered the broad after the novel "Kim", published in 1901-th year by Redyard Kipling. This term became more popular after the Soviet-Afghan events of 1979[2: 61].

The policy of "Great game" began on 12 January 1830, when the president of the Council on Indian Affairs, Lord Ellenbor, instructed the governor of Indian Genoa, William Bentink, to open a new trade route connecting India with the Emirate of Bukhara[3:7].

In the $30-40$ - ies of the XIX century, two conceptions were developed by Great Britain against the policy of Russia in Central Asia: "closed border policy" and "attack Policy". The concept of" attack Policy "( forward policy) was intended to prevent the "Russian threats " that would happen to India without the use of any means (opening War). This concept was formed after the 70 - ies of the XIX century, that is, after the subordination of Khiva, Bukhara and Kokand to Russia. The most active supporters of this concept are the famous Orientalist and military publicists G. Roulinson, Ch. Mak-Gregor and historian J. Malleson was considered. The concept of" closed border policy " (close border policy) meant a policy of avoidance of military action along the borders of India, as well as the expansion of the sphere of influence only through diplomatic means and trade. These views are traveler A. Byorns, the vice - King of India in the years 1864-1869 J. Lawrence, Indian Affairs stats-Secretary gersog Argail and historian J. Key put forward [4: 74].

Diplomat, Imperial official Henry Roulinson-the views of a famous scientist and Asian scholar were reflected in the colonial policy of the Empire developed in relation to Central Asia. G. Roulinson explained his program in a memorandum in 1868. It includes the issues of English-Russian competition, the policy of Russia and England to the countries of Afghanistan, Iran and Central Asia. While he observed the policy of the Russian Empire in Central Asia, he argued that India needed the necessary defence from the attack of the Russian Tsar.

G.Roulinson, as another important principle, the active actions of Russian trade agents in Kokand, Kashgar, Ghulja, emphasizing the need to combat the trade policy of Russia in relation to the countries of Central Asia. He again argued that the British need to open consulates in Ili, Yorkand, Balkh, Herat, which are the main shopping centers in Central Asia.

Among the supporters of the idea that Russia will attack India in the future, there is also a military George Malleson. He is known in Britain for his books such as 
"the history of Afghanistan", "Herat: the threshing and garden of Central Asia", "the English - Russian issue and the attack on India". He advocated the implementation of a policy of active opposition to Russia's policy in Central Asia, saying that the separatist Herat state under British control would be the base point[4:87].

The largest ideologist and performer of British colonial policy in the XIX-XX centuries, who is Kerzon wrote a lot of books on the issues of the countries of Central Asia. The basis of each of the Kerzon views is the need for the necessary defence of the Indian border. He has repeatedly argued that if England enriches India, it will enrich only a small part of its strength. Therefore, England occupied a part of Turkmenistan, emphasizing the need to preserve Russia from the oppression that would happen to India. In his opinion, Rossi's strong position in Central Asia will negatively affect the stability of British rule in India, which is why the main task of Britain is to preserve the British sphere of influence in Afghanistan and Iran, he argued.

In the history of England in the twentieth century J.Morgan's "1810-1895-th years. In Central Asia, the work of English - Russian competition" is considered very popular.

C.Morgan believes that the policy of" Great game " took place between the years 1810 - 1895. In his opinion, the agreement between Russia and Great Britain in 1907 was more inclined to the issue of Europe than to the issue of Central Asia. In practice, however, getting into the sphere of influence of this territory ended in the late nineteenth century. These were noted by the British Ministry of Foreign Affairs, the Asian community, the Royal community of geography and other sources[5:381].

Most of the works of the English authors of the XX century show Rossi's territory to the territories of his troops as a state of aggressive expansion, which seeks to spread its territory. Some of these works will continue even after the disintegration of the former USSR. This shows the strength of the mood of rusophobia in the West[6:26].

From the 20-30 - ies of the XX century until the beginning of World War II, the policy of the "Great game" continued Not only in Iran, Afghanistan, Tibet, but also in the west of China and Mongolia[7:84].

One of the works devoted to the policy of" Great game " is journalists K. Meyer and Sh. Brisak's "Shadow competition: the Great game and the Empire fight for Central Asia". They believe that the policy of the "Great game " lasted from 1810 year until the end of World War II. They consider the object of the" Great game " policy to be Eurasian charted (heart) [7:7].

In place of the conclusion, it should be noted that the reports prepared by the Centers of two confrontational characters of the policy of the "big game", the developed geopolitical goals, the works created are written under the influence of the dominant ideology, and in the sources of both centers it is evident that there is a strong aspiration for domination in the Central Asian Carrying out an objective historical analysis in relation to foreign sources creates an opportunity to bring the original historical truth to the surface.

\section{LIST OF USED LITERATURE}

1. Yapp M.E. The revolution of 1841-1842 in Afghanistan. Bulletin of the School of Oriental and African Studies, University of London.2009.

2. Seymour Becker, "The 'Great game': The history of an evocative phrase." Asian Affairs. 43.1. 2012

3. Edward Ingram. In Defence of British India: Great Britain in the Middle East, 1775-1842. L., 1984 .

4. Charles Weller. Review of The Great Game, 1856-1907: Russo-British Relations in Central and East Asia. 1994.

5. Hopkirk P. The Great Game: the Struggle for Empire in Central Asia. L., 1990.

6. Hopkirk, P. Setting the East ablaze: On Secret Service in Bolshevik Asia. L., 1984.

7. Meyer K.E., Brysac S.B. Tournament of Shadows: The Great Game and the Race for Empire in Central Asia. Washington, 1999. 